\title{
Assessment of acid sulfate soil mapping utilizing chemical indicators in recipient waters
}

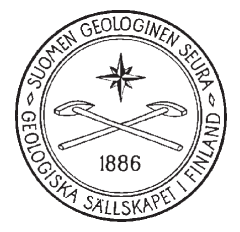

\author{
Amélie Beucher ${ }^{1 *}$, Sören Fröjdö ${ }^{1}$, Peter Österholm ${ }^{1}$, \\ Jaakko Auri ${ }^{2}$, Annu Martinkauppi ${ }^{2}$ and Peter Edén ${ }^{2}$ \\ ${ }^{1}$ Abo Akademi University, Geology and Mineralogy, Domkyrkotorget 1, \\ 20500 Abo, Finland \\ ${ }^{2}$ Geological Survey of Finland, PO Box 97, 67101 Kokkola, Finland
}

\begin{abstract}
In Finland, poor water quality and associated ecological damage in the coastal streams related to land use on acid sulfate (a.s.) soils has been drawing a considerable amount of attention since the 1950's. These soils originate from sulfide-bearing marine sediments mostly occurring in the coastal areas located below the highest shoreline of the former Litorina Sea. Of the many previous studies carried out on soil or water data, quite few gathered both and their geographic extent was relatively limited. This study aimed at assessing a.s. soil probability maps using two chemical indicators measured in the recipient waters (i.e. sulfate content and sulfate/chloride ratio) for 24 catchments along the Finnish coast. All the available data was compiled for these catchments, which were surveyed using different methods (i.e. conventional mapping and two spatial modeling techniques: fuzzy logic and artificial neural networks). High sulfate contents and sulfate/ chloride ratios measured in these rivers were controlled by a.s. soils in the corresponding catchments. The extent of the most probable areas for a.s. soils in the surveyed catchments correlated with the two chemical indicators measured in the recipient waters, suggesting that the probability maps created with different methods are reliable and comparable. The use of a.s. soil related chemical indicators in water, thus, constitutes a complementary, independent and straightforward tool to assess a.s. soil probability maps.
\end{abstract}

Keywords (GeoRef Thesaurus, AGI): acid sulfate soils, mapping, sulfates, drainage basins, rivers, fuzzy logic, artificial intelligence, neural networks, Finland

*Corresponding author (e-mail: amelie.beucher@abo.fi)

Editorial handling: Antti Ojala (antti.ojala@gtk.fi) 


\section{Introduction}

The water quality in many coastal rivers and streams in Finland has been known for decades to suffer from a toxic influx of strong acidity and metals (e.g. $\mathrm{Al}, \mathrm{Cd}, \mathrm{Co}, \mathrm{Ni}, \mathrm{Zn}$ and rare earth elements; Hildén and Rapport, 1993; Hudd and Leskelä, 1998; Åström et al., 2005; Saarinen et al., 2010; Toivonen et al., 2013). A source has been identified in sulfide-bearing sediments, formed under reducing conditions at the bottom of the Baltic Sea since the Litorina Sea stage (starting c. 8,000 years BP, during Holocene). These sediments have emerged because of the strong isostatic land uplift after the last glaciation (today up to $8 \mathrm{~mm} /$ year; Donner, 1995). Then, the upper layers ( 1 to $2 \mathrm{~m}$ ) of these sediments are drained for land use and, thus, get oxidized and form acid sulfate (a.s.) soils, with subsequent acid and metal laden run-off flowing into recipient streams and estuaries (Österholm and Åström, 2002). Hot spot areas cause severe ecological damage and, thus, mapping of these high risk areas is a critical step for effective mitigation. After massive fish kills in 2006 and 2007, the Geological Survey of Finland (GTK) initiated a cooperation network in order to create a nationwide a.s. soil map and mitigate the environmental problems due to these soils. This cooperation work also falls within the scope of the EU Water Framework Directive (2000) which aims at restoring a good status for ground and surface waters in Europe. Within the Finnish a.s. soil mapping project, several spatial modeling methods have been developed to complement conventional mapping. These GIS-based geostatistical methods have been implemented on areas of varying extent and assessed for suitability (Beucher et al., 2013; Beucher et al., 2014).

In this study, we present a compilation of mapping results from several catchments, as well as corresponding water data. Twenty-four catchments located along the Finnish coast were selected as both a.s. soil probability maps and water chemistry data from the mouth of the main river were available for them. These catchments were surveyed using different methods (i.e. conventional mapping and two spatial modeling techniques: fuzzy logic and an artificial neural network technique). Under ideal conditions, the amount of sulfate and metals in a stream is proportional to the extent of a.s. soils in the catchment. We intend, thus, to evaluate the calculated extents of a.s. soils by comparing them to two chemical indicators (i.e. sulfate content and sulfate/chloride ratio) measured in the corresponding rivers. Combining soil and water data may represent a new, straightforward and independent way to assess the reliability and comparability of a.s. soil probability maps.

\section{Study area}

Mapping and modeling were restricted to the coastal areas located below the highest shoreline of the former Litorina Sea (up to $100 \mathrm{~m}$ above the current sea level, covering c. $50,100 \mathrm{~km}^{2}$; Fig. 1) since most of the a.s. soils in Finland are expected to be found in these areas (Yli-Halla et al., 1999). From 62 main coastal catchments (larger than $200 \mathrm{~km}^{2}$, when considering their total drainage area; Table 1), 24 catchments (in all, covering c. $21,300 \mathrm{~km}^{2}$ below the highest shoreline of the former Litorina Sea) were selected for this study (Fig. 1). These catchments can be geographically divided into 4 groups (Fig. 1; Table 1): the southern (i.e. Vehkajoki, Kymijoki, Koskenkylänjoki, Porvoon-Ilolanjoki, Mustijoki, Sipoonjoki River catchments), the southwestern (i.e. Mynäjoki, Laajoki and Sirppujoki River catchments), the western (i.e. Närpiönjoki, Kyrönjoki, Lapuanjoki, Ähtävänjoki and Kruunupyynjoki, Perhonjoki, Lestijoki, Kalajoki, Pyhäjoki, Siikajoki, Temmesjoki and Oulujoki River catchments) and the northwestern (i.e. Kuivajoki, Simojoki and Kemijoki River catchments). Corresponding to the upper Litorina Sea level (c. 9-8 ka), the western and northwestern catchments extend from the coast to $90-100 \mathrm{~m}$ above the current sea level, while the southwestern and southern catchments reach 40-90 m and 20-40 m above the current sea level, respectively. The northwestern catchments and Oulujoki River catchment are underlain by Archean bedrock (around 3.2-2.5 Ga) and younger volcanic and sedimentary rocks (around 2.5-1.89 Ga). The 
$\stackrel{N}{\Lambda}$

Fig. 1. Location of the 24 surveyed catchments (S: southern; SW: southwestern; W: western; NW: northwestern) and diachronous maximum extension of the former Litorina Sea (7,000-9,000 BP; Ojala et al., 2013).

Surveyed areas

Highest shoreline of the Litorina Sea
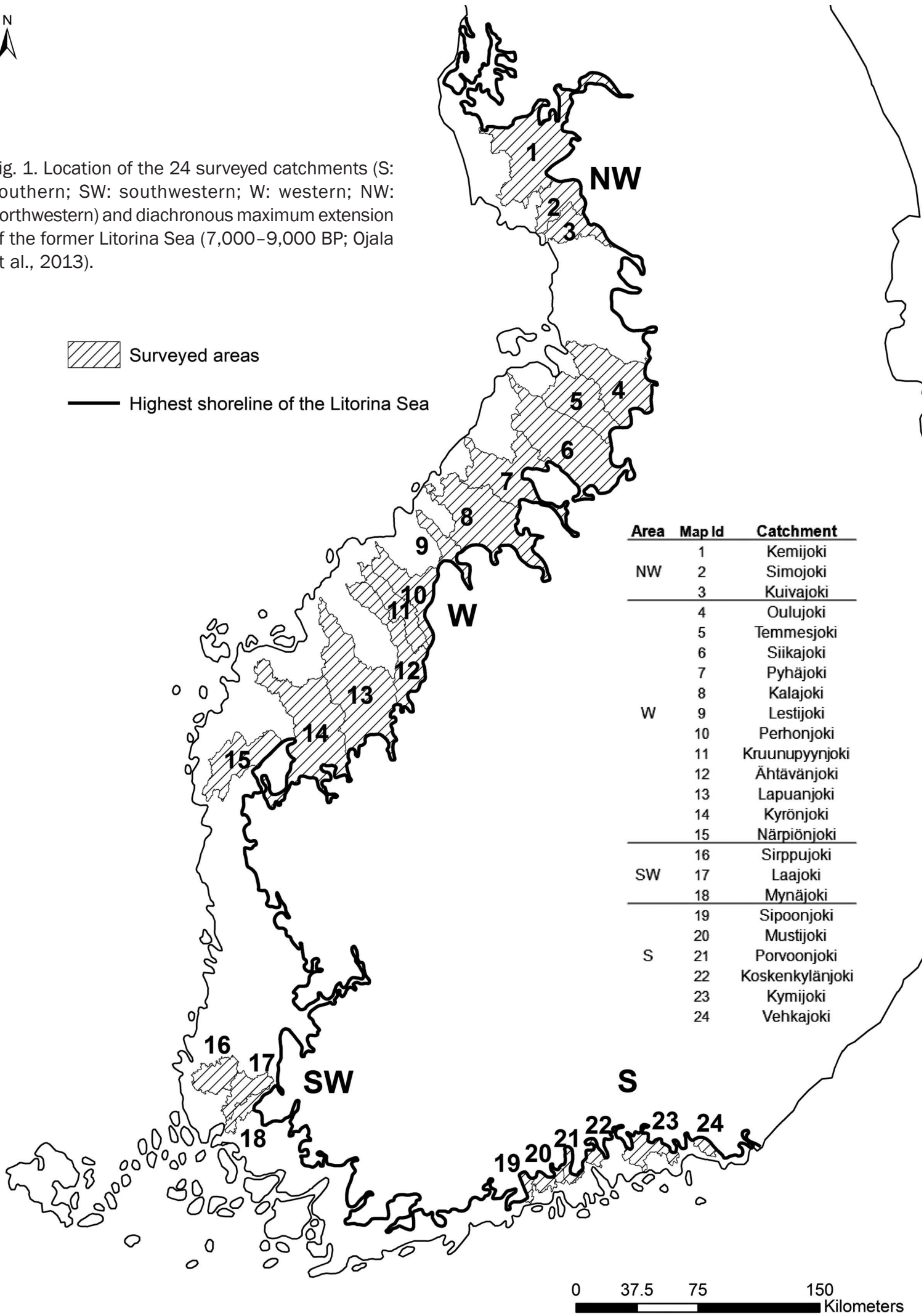
catchments (from Vehkajoki to Temmesjoki) are underlain by Svecofennian bedrock (c. 1.93-1.89 $\mathrm{Ga}$ ), comprising volcanic and sedimentary rocks which were folded, metamorphosed and intruded by granitoids and mafic rocks (Taipale and Saarnisto, 1990). Carbonaceous rocks are notably scarce and largely occur as marble within the crystalline bedrock. The ancient bedrock is mostly covered by glacial and post-glacial Quaternary deposits, such as till, glaciofluvial sediments (i.e. eskers, sand and gravel), littoral sediments (i.e. sand and gravel), marine and lacustrine clays, silt and peat (Donner, 1995). These Quaternary sediments were mainly formed and deposited during the late Weichselian glaciation and the following deglaciation phases (about 28-10 ka), the Ancylus-Lake (about 10.7$9.8 \mathrm{ka}$ ) and Litorina-Sea stages (starting at about 9-8 ka) which led to the actual Baltic Sea (Wohlfarth et al., 2008). In most of the catchments, forest is the dominant land cover type (50-80\% and median: $69 \%$; Table 1). The proportion of cultivated land, which mainly constitutes the fine-grained sediments, is also significant, except in the northernmost catchments (i.e. Oulujoki, Kuivajoki, Simojoki and Kemijoki River catchments) where peat is more dominant (Table 1).

Table 1. Drainage area and proportion of cultivated land, forest, peat, water and other land types (e.g. urban, industrial areas), as well as the proportion of the drainage area below the highest shoreline of the former Litorina Sea for the different surveyed catchments (OIVA-environment and geographic information service, Finnish Environment Institute).

\begin{tabular}{|c|c|c|c|c|c|c|c|c|}
\hline Area & River & $\begin{array}{c}\text { Drainage } \\
\text { area } \\
\left(\mathrm{km}^{2}\right)\end{array}$ & $\begin{array}{c}\text { Cultivated } \\
\text { (\%) }\end{array}$ & $\begin{array}{c}\text { Forest } \\
(\%)\end{array}$ & $\begin{array}{l}\text { Peat } \\
(\%)\end{array}$ & $\begin{array}{c}\text { Water } \\
(\%)\end{array}$ & $\begin{array}{c}\text { Other } \\
(\%)\end{array}$ & $\begin{array}{c}\text { Below } \\
\text { Litorina } \\
\quad(\%)\end{array}$ \\
\hline NW & $\begin{array}{l}\text { Kemijoki } \\
\text { Simojoki } \\
\text { Kuivajoki }\end{array}$ & $\begin{array}{r}51,130 \\
3,160 \\
1,360\end{array}$ & $\begin{array}{l}0.7 \\
1.6 \\
2.2\end{array}$ & $\begin{array}{l}80.2 \\
73.7 \\
69.1\end{array}$ & $\begin{array}{l}14.6 \\
19.3 \\
25.7\end{array}$ & $\begin{array}{l}4.2 \\
5.4 \\
2.8\end{array}$ & $\begin{array}{l}0.3 \\
0.1 \\
0.1\end{array}$ & $\begin{array}{r}4 \\
18 \\
38\end{array}$ \\
\hline W & $\begin{array}{l}\text { Oulujoki } \\
\text { Temmesjoki } \\
\text { Siikajoki } \\
\text { Pyhäjoki } \\
\text { Kalajoki } \\
\text { Lestijoki } \\
\text { Perhonjoki } \\
\text { Kruunupyynjoki } \\
\text { Ähtävänjoki } \\
\text { Lapuanjoki } \\
\text { Kyrönjoki } \\
\text { Närpiönjoki }\end{array}$ & $\begin{array}{r}22,840 \\
1,180 \\
4,320 \\
3,710 \\
4,250 \\
1,370 \\
2,520 \\
790 \\
2,050 \\
4,120 \\
4,920 \\
990\end{array}$ & $\begin{array}{r}2.3 \\
21.2 \\
11.6 \\
13.2 \\
19.1 \\
13.1 \\
13.1 \\
16.5 \\
17.6 \\
26.0 \\
29.3 \\
24.2\end{array}$ & $\begin{array}{l}78.0 \\
59.3 \\
74.1 \\
75.9 \\
73.2 \\
68.6 \\
70.2 \\
73.4 \\
66.8 \\
64.8 \\
61.0 \\
66.7\end{array}$ & $\begin{array}{r}7.3 \\
17.8 \\
12.0 \\
4.9 \\
4.5 \\
11.7 \\
13.1 \\
7.6 \\
3.9 \\
4.9 \\
6.1 \\
7.1\end{array}$ & $\begin{array}{r}11.5 \\
0.4 \\
2.1 \\
4.9 \\
1.6 \\
5.8 \\
2.8 \\
1.5 \\
9.8 \\
2.4 \\
1.0 \\
0.6\end{array}$ & $\begin{array}{l}0.9 \\
1.3 \\
0.2 \\
1.1 \\
1.6 \\
0.7 \\
0.8 \\
1.0 \\
2.0 \\
1.9 \\
2.6 \\
1.4\end{array}$ & $\begin{array}{r}6 \\
85 \\
51 \\
36 \\
44 \\
27 \\
33 \\
80 \\
49 \\
54 \\
47 \\
90\end{array}$ \\
\hline SW & $\begin{array}{l}\text { Sirppujoki } \\
\text { Laajoki } \\
\text { Mynäjoki }\end{array}$ & $\begin{array}{l}400 \\
390 \\
290\end{array}$ & $\begin{array}{l}35.3 \\
18.5 \\
29.3\end{array}$ & $\begin{array}{l}59.0 \\
70.8 \\
65.5\end{array}$ & $\begin{array}{l}1.8 \\
8.2 \\
1.7\end{array}$ & $\begin{array}{l}0.3 \\
1.8 \\
0.3\end{array}$ & $\begin{array}{l}3.8 \\
0.8 \\
3.1\end{array}$ & $\begin{array}{r}100 \\
100 \\
72\end{array}$ \\
\hline$S$ & $\begin{array}{l}\text { Sipoonjoki } \\
\text { Mustijoki } \\
\text { Porvoonjoki } \\
\text { Koskenkylänjoki } \\
\text { Kymijoki } \\
\text { Vehkajoki }\end{array}$ & $\begin{array}{r}220 \\
780 \\
1,580 \\
900 \\
37,160 \\
380\end{array}$ & $\begin{array}{r}40.9 \\
37.2 \\
36.7 \\
35.6 \\
7.9 \\
17.1\end{array}$ & $\begin{array}{l}50.0 \\
57.7 \\
57.0 \\
57.8 \\
71.9 \\
75.3\end{array}$ & $\begin{array}{l}0.0 \\
1.2 \\
0.3 \\
0.6 \\
1.1 \\
1.8\end{array}$ & $\begin{array}{r}0.5 \\
1.3 \\
1.9 \\
4.7 \\
17.7 \\
3.9\end{array}$ & $\begin{array}{l}8.6 \\
2.7 \\
4.1 \\
1.4 \\
1.5 \\
1.8\end{array}$ & $\begin{array}{r}41 \\
15 \\
12 \\
13 \\
1 \\
28\end{array}$ \\
\hline
\end{tabular}

NB: S: southern; SW: southwestern; W: western; NW: northwestern. 


\section{Material}

\subsection{Soil samples}

Soil profiles and probing points were used for both conventional mapping and the spatial modeling techniques. Using a portable auger, the soil profiles were sampled at vertical depth intervals of $20 \mathrm{~cm}$ down to $3 \mathrm{~m}$ depth. For the probing points, a different auger was utilized and the soil/parent material was generally sampled at one to three different depths depending on the sediment lithology. Two different studies were conducted using soil profiles and/or probing points. Within the artificial neural network (ANN) study (Beucher et al., 2013), only soil profiles were used as training and validation points while within the fuzzy logic study soil profiles and probing points were used as validation points. This study utilized more than 4,000 soil profiles and probing points collected 20092013 (Table 2), the work coordinated by GTK. The sampling sites were chosen so that the data sets were representative of the respective catchments. Within $24 \mathrm{~h}$ from sampling, $\mathrm{pH}$ was measured for each sample (deionized water in a proportion of c. 1:1 was added to allow proper contact between the electrode and the soil material). Selected samples were also analyzed for sulfur with ICP-OES after digestion with aqua regia. For samples with a field $\mathrm{pH}$ higher than 4.0, $\mathrm{pH}$ was measured again after 9 to 16 weeks of incubation at room temperature. Soil profiles were considered as actual a.s. soils when they comprised an oxidised acidic layer ( $\mathrm{pH}$ lower than 4.0) with an underlying sulfidic horizon within $3 \mathrm{~m}$ depth. They were considered as potential a.s. soils when $\mathrm{pH}$ decreased at least by 0.5 units to a value lower or equal to 4.0 after incubation (Soil Survey Staff, 1999; Edén et al., 2012). In the case of the Sirppujoki River catchment, a small number of soil profiles ( $\mathrm{n}=13$ ) previously studied by Triipponen (1997) was additionnally used (Beucher et al, 2013). Within the a.s. soil probability mapping, the a.s. and non-a.s. soil occurrences are considered as positive and negative points, respectively (Table 2).

\subsection{Water samples}

For most of the catchments $(\mathrm{n}=21)$, water data (sulfate and chloride contents, as well as $\mathrm{pH}$ and electric conductivity) was extracted from the HERT-

Table 2. Number of soil profiles and probing points, divided as positive and negative points (i.e. a.s. and non-a.s. soil occurrences, respectively) for each catchment.

\begin{tabular}{|c|c|c|c|c|}
\hline Area & Catchment & Method & $\begin{array}{l}\text { Positive } \\
\text { points } \\
\text { (n) }\end{array}$ & $\begin{array}{c}\text { Negative } \\
\text { points } \\
\text { (n) }\end{array}$ \\
\hline NW & $\begin{array}{l}\text { Kemijoki } \\
\text { Simojoki } \\
\text { Kuivajoki }\end{array}$ & $\begin{array}{l}\mathrm{FL} \\
\mathrm{FL} \\
\mathrm{FL}\end{array}$ & $\begin{array}{l}60 \\
16 \\
\text { n.a. }\end{array}$ & $\begin{array}{l}61 \\
42 \\
\text { n.a. }\end{array}$ \\
\hline W & $\begin{array}{l}\text { Oulujoki } \\
\text { Temmesjoki } \\
\text { Siikajoki } \\
\text { Pyhäjoki } \\
\text { Kalajoki } \\
\text { Lestijoki } \\
\text { Perhonjoki } \\
\text { Kruunupyynjoki } \\
\text { Ähtävänjoki } \\
\text { Lapuanjoki } \\
\text { Kyrönjoki } \\
\text { Närpiönjoki }\end{array}$ & $\begin{array}{l}\text { FL } \\
\text { FL } \\
\text { Conv } \\
\text { Conv } \\
\text { FL } \\
\text { FL } \\
\text { FL } \\
\text { Conv } \\
\text { Conv } \\
\text { Conv } \\
\text { Conv } \\
\text { Conv }\end{array}$ & $\begin{array}{c}\text { n.a. } \\
\text { n.a. } \\
241 \\
48 \\
120 \\
27 \\
26 \\
102 \\
108 \\
241 \\
498 \\
76\end{array}$ & $\begin{array}{c}\text { n.a. } \\
\text { n.a. } \\
515 \\
197 \\
326 \\
38 \\
49 \\
134 \\
150 \\
218 \\
613 \\
20\end{array}$ \\
\hline SW & $\begin{array}{l}\text { Sirppujoki } \\
\text { Laajoki } \\
\text { Mynäjoki }\end{array}$ & $\begin{array}{c}\text { RBFLN } \\
\text { Conv } \\
\text { Conv }\end{array}$ & $\begin{array}{l}49 \\
13 \\
11\end{array}$ & $\begin{array}{c}13(+36) \\
25 \\
41\end{array}$ \\
\hline $\mathrm{S}$ & $\begin{array}{l}\text { Sipoonjoki } \\
\text { Mustijoki } \\
\text { Porvoonjoki } \\
\text { Koskenkylänjoki } \\
\text { Kymijoki } \\
\text { Vehkajoki }\end{array}$ & $\begin{array}{l}\text { FL } \\
\text { FL } \\
\text { Conv } \\
\text { FL } \\
\text { FL } \\
\text { FL }\end{array}$ & $\begin{array}{l}\text { n.a. } \\
\text { n.a. } \\
15 \\
\text { n.a. } \\
\text { n.a. } \\
\text { n.a. }\end{array}$ & $\begin{array}{c}\text { n.a. } \\
\text { n.a. } \\
5 \\
\text { n.a. } \\
\text { n.a. } \\
\text { n.a. }\end{array}$ \\
\hline
\end{tabular}

NB: S: southern; SW: southwestern; W: western; NW: northwestern; Conv: conventional mapping; FL: fuzzy logic; RBFLN: Radial Basis Functional Link Net (ANN); n.a.: not available; $* 36$ additional sites were also used as negative points; they were extracted randomly from the lowest probability areas of a map previously generated using another technique called weights-of-evidence analysis (Beucher et al., 2013). 
TA database (2014; OIVA-environment and geographic information service, Finnish Environment Institute). For the 3 remaining catchments (i.e. Mynäjoki, Laajoki and Sirppujoki River catchments), water data was taken from $\mathrm{Ny}$ berg et al. (2011). In all, 235 samples were included in this study (Tables 3 and 6). Water was sampled close to the mouth of the river during spring 2002 2012, from April to June. Electric conductivity and $\mathrm{pH}$ were measured in the field. The samples were filtered $(0.45 \mu \mathrm{m})$ before being analyzed for sulfate and chloride content by ion chromatography for samples from Hertta database and by ICP-OES for samples from Nyberg et al. (2011).

\subsection{Raster datasets}

The spatial modeling techniques required the use of various datalayers (described in Table 3). The digital Quaternary geology maps were used to target fine-grained sediments in which a.s. soils are most likely to occur. Since a.s. soils are generally located in low-relief, low-lying areas (i.e. plains, marshes and river valleys), a simple slope model was created from a basic low-resolution DEM in order to distinguish these soils from till morphology and bedrock outcrops. The low electromagnetic frequency $(3 \mathrm{kHz})$ imaginary and real components were derived from high resolution low altitude airborne geophysics. The imaginary component enables the detection of shallow anomalies which are mainly related to variations in the top-soil thickness and/or electric conductivity. The real component indicates anomalies originating deep in the bedrock, for instance from black schist. Sulfidebearing sediments are expected to yield strong electromagnetic anomalies due to their high contents of soluble salts (Vanhala et al., 2004; Suppala et al., 2005). They appear as diffuse and round-shaped high electric conductivity anomalies. Black schists are often associated with sulfide deposits and might also cause high metal contents in soil or ground water (Airo and Loukola-Ruskeeniemi, 2004). They appear as thin and elongated anomalies. When black schists occurred in one of our study areas, they were taken into account within the interpretation of the modeling results. The Quaternary geology and aerogeophysical datalayers were produced by GTK, and the DEMs by the National Land Survey (MML).

\section{Methods}

Among the 24 different catchments discussed in this study, 13 were assessed at reconnaissance scale (i.e. as a preliminary survey) using fuzzy logic (among which 5 were already studied in Beucher et al., 2014), 10 were conventionally mapped by GTK and 1 was assessed using an ANN technique (Beucher et al., 2013). An overview of the material and methods utilized in this study is presented in Table 3. Notably, all the soil profiles and probing points corresponding to a.s. or non-a.s. soils were utilized for conventional mapping, while, for the catchments modeled with fuzzy logic, a significantly smaller amount of soil profiles and probing points were used for validation as only about 1 site per 2 $\mathrm{km}^{2}$ was randomly selected (Table 2 ). Within the fuzzy logic or ANN modeling, the same grid cell size $(50 \mathrm{~m} \times 50 \mathrm{~m})$ was applied to the evidential datalayers.

\subsection{Conventional mapping}

The conventional mapping process can be divided into three steps. Prior to the soil sampling in the field, various datalayers (aerogeophysical data, bedrock geology, Quaternary geology, peatland and elevation data) are utilized in an exploratory manner to prioritize areas of interest (Österholm et al., 2010; Edén et al., 2012). A soil sampling plan covering all potential areas is established. Secondly, soil sampling is carried out, $\mathrm{pH}$ is measured in the field and after 9 to 16 weeks of incubation, and selected samples are subsequently analyzed for sulfur. Finally, the a.s. soil maps are drawn at 1:125,000 scale based on the combined manual interpretation of the following data: field observations, mesurements and further analyses, topographic maps (i.e. DEMs provided by MML), Quaternary geology, peatland and aerogeophysical data (produced by GTK). 
Table 3. Overview of material and methods in this study.

\begin{tabular}{|c|c|c|c|}
\hline Method & Conventional mapping & Fuzzy logic & RBFLN \\
\hline Study area(s) & $\begin{array}{l}10 \text { catchments: } \\
\text { Porvoonjoki, Mynäjoki, Laajoki, } \\
\text { Närpiönjoki, Kyrönjoki, Lapuanjoki, } \\
\text { Ähtävänjoki, Kruunupyynjoki, Pyhäjoki, } \\
\text { Siikajoki }\end{array}$ & $\begin{array}{l}13 \text { catchments: } \\
\text { Vehkajoki, Kymijoki, Koskenkylänjoki, } \\
\text { Mustijoki, Sipoonjoki, Perhonjoki, } \\
\text { Lestijoki, Kalajoki, Temmesjoki, } \\
\text { Oulujoki, Kuivajoki, Simojoki, } \\
\text { Kemijoki }\end{array}$ & Sirppujoki River catchment \\
\hline Datalayers & $\begin{array}{l}\text { 1:20,000 Quaternary geology } \\
\text { 1:200,000 Quaternary geology } \\
2 \text { aerogeophysical datalayers*: } \\
\text { imaginary component } \\
\text { real component } \\
\text { DEM \& LiDAR-based DEM*** } \\
\text { Bedrock geology } \\
\text { Peatland }\end{array}$ & $\begin{array}{l}\text { 1:200,000 Quaternary geology } \\
1 \text { aerogeophysical datalayer*: } \\
\text { imaginary component }\end{array}$ & 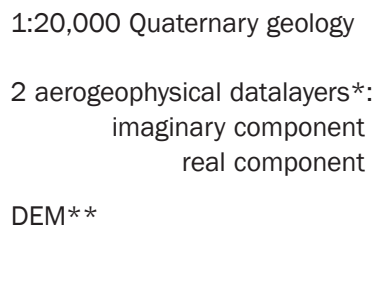 \\
\hline Soil samples & 3271 profiles and probing points & $\begin{array}{l}\text { For validation: } \\
\quad 765 \text { profiles and probing points }\end{array}$ & $\begin{array}{l}\text { For training and validation: } \\
\qquad 62 \text { profiles }\end{array}$ \\
\hline Water samples & 89 & 144 & 2 \\
\hline
\end{tabular}

NB: * High resolution low altitude airborne geophysics, flight altitude 30-40 m and line spacing $200 \mathrm{~m}$;

** Original cell size $25 \times 25 \mathrm{~m}$ and elevation data accuracy $2 \mathrm{~m}$;

$* * *$ Original cell size $2 \times 2 \mathrm{~m}$ and elevation data accuracy $0.3 \mathrm{~m}$.

\subsection{Fuzzy logic}

Fuzzy logic constitutes a conceptual approach for spatial modeling, based on expert knowledge (Bonham-Carter, 1994). This method is generally selected when an insufficient number or even no known occurrences are available to carry out a statistical analysis. Fuzzy logic enables dealing with uncertainties inherent in complex natural phenomena (McBratney and Odeh, 1997). This method originates from the fuzzy-set theory, introduced by Zadeh (1965), which defines a degree of membership, a value between 0 and 1 without crisp boundary, for a set. 0 indicates the full nonmembership of $\mathrm{x}$ in the fuzzy set ("not indicator") and 1 the full membership of $x$ ("indicator"). Different evidential datalayers are used as input data within this modeling method (i.e. Quaternary geology, slope and imaginary component). For this study, the fuzzy logic modeling was carried out using ArcGIS $10^{\mathrm{TM}}$ (ESRI software) and a public-domain extension for multivariate analysis called Spatial Data Modeller (SDM; Sawatzky et al., 2009).

\subsection{Artificial neural networks}
ANNs constitute standard machine-learning techniques providing powerful pattern recognition and classification tools. ANNs are basically designed to learn how to classify new, unknown data using known examples for training. They are thus considered as data-driven techniques based on a supervised learning algorithm (Bonham-Carter, 1994; Zell, 1998). Different evidential datalayers are also used as input data within the modeling (i.e. Quaternary geology, slope, real and imaginary component). Being able to approximate non-linear functions of their inputs, ANNs enable the predictive modeling of complex natural situations involving intricate chemical and physical processes which are not directly observable. They also deal with uncertainty related to input data. 
In this study, an ANN called Radial Basis Functional Link Net (RBFLN) was applied to the Sirppujoki River catchment (Beucher et al., 2013). This network, using Radial Basis Functions (RBFs) as activation functions, presents simple training algorithms and architecture, and also trains more quickly than multiple layered perceptron (MLP) networks (i.e. a common sort of ANNs; Looney, 2002). The RBFLN modeling was solely performed using ArcGIS 10 (ESRI software) and a publicdomain extension for multivariate analysis called Spatial Data Modeler (SDM; Sawatzky et al., 2009). Looney (2002) states the advantages of an RBFLN: (1) it includes both non-linear functions (through the Gaussian activation function) and linear connections between the input and output layers, and (2) a smaller number of hidden neurons can be used.

\section{Results}

\subsection{Validation of the modeled catchments}

The validation results for the modeled catchments are summarized in Table 4. For the most accurate RBFLN probability map (Fig. 2), $94 \%$ of the a.s. soil occurrences (i.e. positive points) are properly classified in the combined high and moderate probability areas while all the non-a.s. soil occurrences (i.e. negative points) are properly classified in the combined low and very low

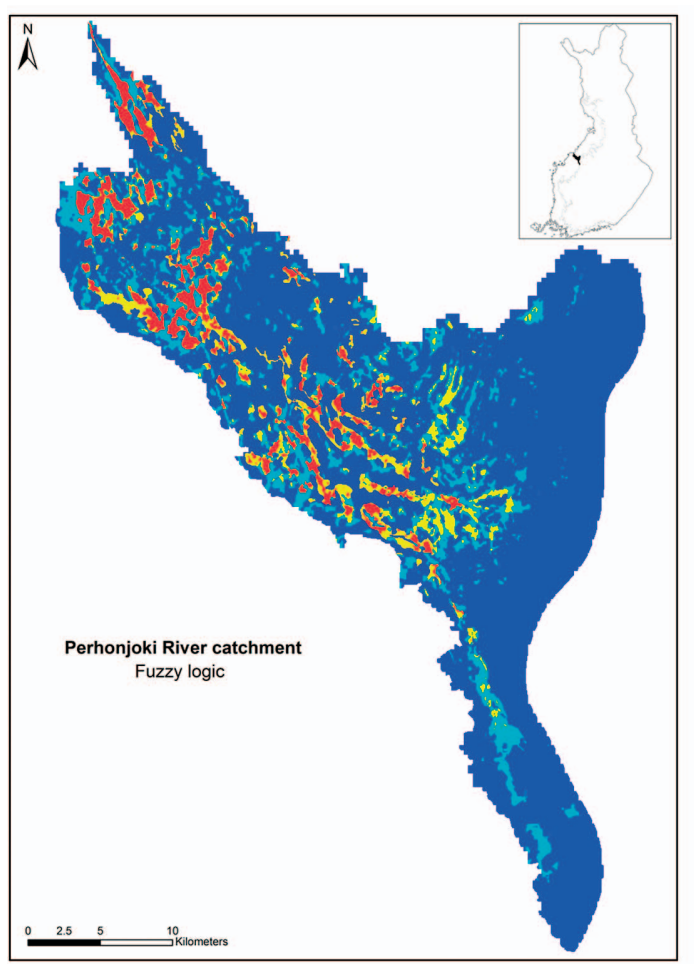

Fuzzy logic and ANN probability classes

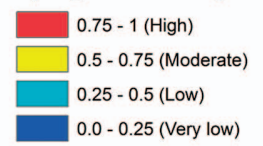

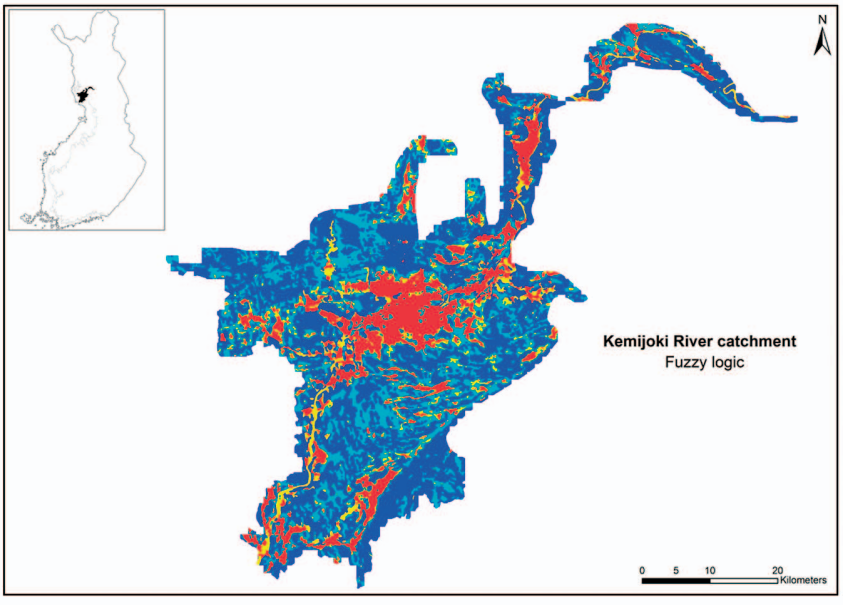

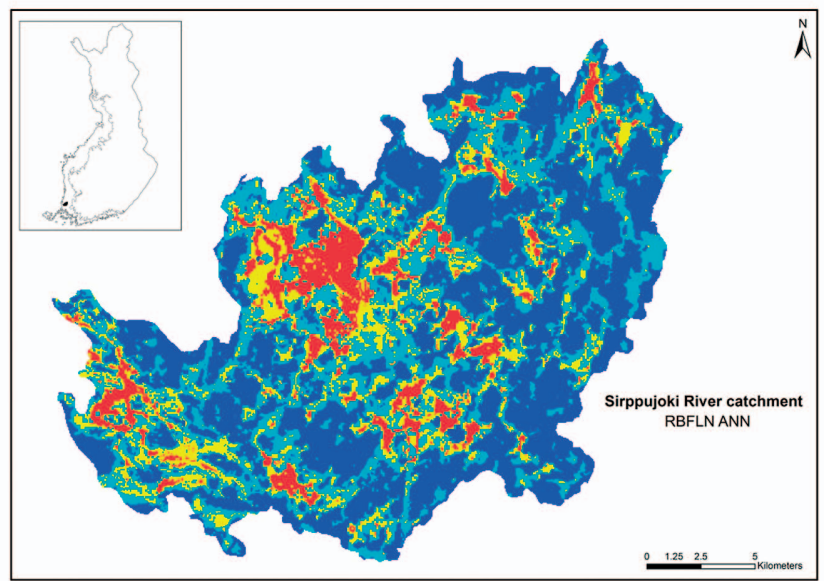

GCS-KKJ: Finnish Uniform Coordinate System

Fig. 2. Examples of a.s. soil probability maps for Sirppujoki, Perhonjoki and Kemijoki River catchments. 
probability areas (Beucher et al., 2013). Among the catchments modeled with fuzzy logic, validation points were available for Kemijoki, Simojoki, Kalajoki, Lestijoki and Perhonjoki River catchments. For these catchments, 47 to $82 \%$ of a.s. soil occurrences were correctly assigned to the combined high and moderate probability areas, while 77 to $94 \%$ of the non-a.s. soil occurrences were correctly assigned to the combined low and very low probability areas (Table 4; Fig. 2). The small southern catchments (i.e. Vehkajoki, Kymijoki, Koskenkylänjoki, Mustijoki and Sipoonjoki River catchments) were modeled for a study by Beucher et al. (2014), but no validation points were available for them.

\subsection{Extent of a.s. soils}

Two different values on the relative extent of a.s. soils were calculated for the 24 catchments, taking into account the whole catchment: one corresponding to the high probability areas alone and one to the combined high and moderate probability areas (Table 5). Six catchments in the western region (i.e. Närpiönjoki, Kyrönjoki,
Lapuanjoki, Ähtävänjoki, Kruunupyynjoki and Temmesjoki River catchments), as well as Sirppujoki River catchment in the southwestern region and Sipoonjoki River catchment in the southern region, display the largest extent values for both high probability areas (4.7-46.6\%) and the combination of high and moderate probability areas (8.2-47.2 $\%$; Table 5). The southern and southwestern catchments (excluding Sirppujoki River catchment) display relatively small extent values (0.02-3.9\% for the high probability areas and $0.1-11.6 \%$ for the combined high and moderate probability areas; Table 5). The remaining catchments in the western region (i.e. Perhonjoki, Lestijoki, Kalajoki, Pyhäjoki, Siikajoki and Oulujoki River catchments) also display small extent values $(0.4-3.1 \%$ for the high probability areas and $0.8-5.7 \%$ for the combined high and moderate probability areas; Table 5). The northwestern catchments present the smallest extent values $(0.1-1.6 \%$ for the high probability areas and $0.2-1.8 \%$ for the combined high and moderate probability areas; Table 5). While most of the catchments were dominated by areas below the Litorina limit, the catchments of Kymijoki, Oulu-

Table 4. Validation results for the catchments modeled with fuzzy logic or RBFLN.

\begin{tabular}{|c|c|c|c|c|c|c|}
\hline Area & Catchment & Method & $\begin{array}{l}\text { Positive points } \\
\text { (n) }\end{array}$ & $\begin{array}{l}\text { Properly assigned } \\
\text { positive points (\%) }\end{array}$ & $\begin{array}{l}\text { Negative points } \\
\text { (n) }\end{array}$ & $\begin{array}{l}\text { Properly assigned } \\
\text { negative points (\%) }\end{array}$ \\
\hline NW & $\begin{array}{l}\text { Kemijoki } \\
\text { Simojoki } \\
\text { Kuivajoki }\end{array}$ & $\begin{array}{l}\mathrm{FL} \\
\mathrm{FL} \\
\mathrm{FL}\end{array}$ & $\begin{array}{l}60 \\
16 \\
\text { n.a. }\end{array}$ & $\begin{array}{c}82 \\
56 \\
-\end{array}$ & $\begin{array}{l}61 \\
42 \\
\text { n.a. }\end{array}$ & $\begin{array}{c}77 \\
90 \\
-\end{array}$ \\
\hline W & $\begin{array}{l}\text { Oulujoki } \\
\text { Temmesjoki } \\
\text { Kalajoki } \\
\text { Lestijoki } \\
\text { Perhonjoki }\end{array}$ & $\begin{array}{l}\mathrm{FL} \\
\mathrm{FL} \\
\mathrm{FL} \\
\mathrm{FL} \\
\mathrm{FL}\end{array}$ & $\begin{array}{c}\text { n.a. } \\
\text { n.a. } \\
120 \\
27 \\
26\end{array}$ & $\begin{array}{c}- \\
- \\
47 \\
59 \\
69\end{array}$ & $\begin{array}{c}\text { n.a. } \\
\text { n.a. } \\
326 \\
38 \\
49\end{array}$ & $\begin{array}{l}- \\
- \\
83 \\
97 \\
94\end{array}$ \\
\hline SW & Sirppujoki & RBFLN & 49 & 94 & 49 & 100 \\
\hline S & $\begin{array}{l}\text { Sipoonjoki } \\
\text { Mustijoki } \\
\text { Koskenkylänjoki } \\
\text { Kymijoki } \\
\text { Vehkajoki }\end{array}$ & $\begin{array}{l}\mathrm{FL} \\
\mathrm{FL} \\
\mathrm{FL} \\
\mathrm{FL} \\
\mathrm{FL}\end{array}$ & $\begin{array}{l}\text { n.a. } \\
\text { n.a. } \\
\text { n.a. } \\
\text { n.a. } \\
\text { n.a. }\end{array}$ & $\begin{array}{l}- \\
- \\
- \\
- \\
-\end{array}$ & $\begin{array}{l}\text { n.a. } \\
\text { n.a. } \\
\text { n.a. } \\
\text { n.a. } \\
\text { n.a. }\end{array}$ & $\begin{array}{l}- \\
- \\
- \\
-\end{array}$ \\
\hline
\end{tabular}

NB: S: southern; SW: southwestern; W: western; NW: northwestern; FL: fuzzy logic; RBFLN: Radial Basis Functional Link Net (ANN); n.a.: not available. 
joki and Kemijoki Rivers notably were about one magnitude larger than the other catchments, strongly dominated by areas above the Litorina limit (i.e. areas without a.s. soils; Table 1). Consequently, although the total area of a.s. soils was large for the latter two catchments, the relative extent was rather small.

\subsection{Sulfate content and sulfate/ chloride ratio in the rivers}

For the 24 surveyed catchments, the sulfate content in the corresponding rivers ranged between 1.1 and $98.8 \mathrm{mg} / \mathrm{l}$ with a median value of $13.8 \mathrm{mg} / \mathrm{l}$ (Table

Table 5. Extent of the a.s. soil probability areas in surveyed catchments along the Finnish coast; areas above the highest shoreline of the former Litorina Sea included in the estimates.

\begin{tabular}{|c|c|c|c|c|c|c|}
\hline \multirow{3}{*}{ Area } & \multirow{3}{*}{ Catchment } & \multirow{3}{*}{$\begin{array}{c}\text { Drainage } \\
\text { area } \\
\left(\mathrm{km}^{2}\right)\end{array}$} & \multicolumn{4}{|c|}{ Extent of a.s. soil probability areas } \\
\hline & & & \multicolumn{2}{|c|}{ High } & \multicolumn{2}{|c|}{$\begin{array}{l}\text { High and } \\
\text { moderate }\end{array}$} \\
\hline & & & $\left(\mathrm{km}^{2}\right)$ & $(\%)$ & $\left(\mathrm{km}^{2}\right)$ & $(\%)$ \\
\hline \multirow{3}{*}{ NW } & Kemijoki & 51,130 & 370.0 & 0.7 & 480.0 & 0.9 \\
\hline & Simojoki & 3,160 & 3.0 & 0.1 & 5.5 & 0.2 \\
\hline & Kuivajoki & 1,360 & 22.0 & 1.6 & 24.0 & 1.8 \\
\hline \multirow{12}{*}{ W } & Oulujoki & 22,840 & 157.0 & 0.7 & 187.0 & 0.8 \\
\hline & Temmesjoki & 1,180 & 550.0 & 46.6 & 557.0 & 47.2 \\
\hline & Siikajoki & 4,320 & 96.0 & 2.2 & 246.0 & 5.7 \\
\hline & Pyhäjoki & 3,710 & 24.0 & 0.6 & 63.0 & 1.7 \\
\hline & Kalajoki & 4,250 & 17.0 & 0.4 & 116.0 & 2.7 \\
\hline & Lestijoki & 1,370 & 29.0 & 2.1 & 48.0 & 3.5 \\
\hline & Perhonjoki & 2,520 & 77.0 & 3.1 & 122.0 & 4.8 \\
\hline & Kruunupyynjoki & 790 & 67.0 & 8.5 & 112.0 & 14.2 \\
\hline & Ähtävänjoki & 2,050 & 96.0 & 4.7 & 168.0 & 8.2 \\
\hline & Lapuanjoki & 4,120 & 283.0 & 6.9 & 636.0 & 15.4 \\
\hline & Kyrönjoki & 4,920 & 580.0 & 11.8 & 784.0 & 15.9 \\
\hline & Närpiönjoki & 990 & 113.0 & 11.4 & 272.0 & 27.4 \\
\hline \multirow{3}{*}{ SW } & Sirppujoki & 400 & 35.9 & 9.0 & 93.4 & 23.4 \\
\hline & Laajoki & 390 & 1.4 & 0.4 & 27.0 & 6.9 \\
\hline & Mynäjoki & 290 & 4.0 & 1.4 & 20.0 & 6.9 \\
\hline \multirow{6}{*}{$\mathrm{S}$} & Sipoonjoki & 220 & 8.6 & 3.9 & 25.6 & 11.6 \\
\hline & Mustijoki & 780 & 6.2 & 0.8 & 19.2 & 2.5 \\
\hline & Porvoonjoki & 1,580 & 12.0 & 0.8 & 59.0 & 3.7 \\
\hline & Koskenkylänjoki & 900 & 29.1 & 3.3 & 47.5 & 5.3 \\
\hline & Kymijoki & 37,160 & 8.7 & 0.0 & 46.1 & 0.1 \\
\hline & Vehkajoki & 380 & 0.8 & 0.2 & 3.1 & 0.8 \\
\hline
\end{tabular}

NB: S: southern; SW: southwestern; W: western; NW: northwestern
6 and Fig. 3). In general, high concentrations of sulfate were found in a group of rivers in the western region (i.e. Närpiönjoki, Kyrönjoki, Lapuanjoki, Ähtävänjoki, Kruunupyynjoki and Pyhäjoki Rivers; 12-53 mg/l and median: $35 \mathrm{mg} / \mathrm{l}$; Table 6). Nevertheless, the highest sulfate contents were measured in Sirppujoki River (89.8-98.8 mg/l and median: $94.3 \mathrm{mg} / \mathrm{l}$; Table 6 ) and Temmesjoki River (23-92 mg/l and median: $42 \mathrm{mg} / \mathrm{l}$; Table 6). The remaining rivers in the western region (i.e. Perhonjoki, Lestijoki, Kalajoki, Siikajoki and Oulujoki Rivers) are defined by lower sulfate contents (3-19 mg/l and median: $9.4 \mathrm{mg} / \mathrm{l}$; Table 6). The southwestern rivers (Sirppujoki River excluded) are characterized by intermediate sulfate contents, (18-32.9 mg/l and median: $24 \mathrm{mg} / \mathrm{l}$; Table 6). The southern rivers are defined by relatively low sulfate contents (7.3-26.2 mg/l and median: 12.7 $\mathrm{mg} / \mathrm{l}$; Table 6). The northwestern rivers are characterized by the lowest sulfate contents (1.1-4.3 $\mathrm{mg} / \mathrm{l}$ and median: $1.8 \mathrm{mg} / \mathrm{l}$; Table 6).

Originally sulfide and choride were retained in the sediments. However, in contrast to a slow natural leaching of chloride, oxidation affects sulfide which is heavily enriched (as sulfate) in the run-off. Therefore, a higher sulfate/chloride ratio could constitute an indicator for the presence of oxidised a.s. soils in Boreal environments. The ratio ranges between 1.4 and 8.6 with a median value of 2.9 in the studied rivers (Table 6 ). The western rivers, together with Sirppujoki River, have high sulfate/chloride ratios (2.6-8.6 and median: 4.7; Table 6) while the ratios in the remaining rivers are lower (1.4-2.6 and median: 2.1; Table 6 and Fig. 3). 
Table 6. Sulfate content and sulfate/chloride ratio in the rivers corresponding to the surveyed catchments along the Finnish coast.

\begin{tabular}{|c|c|c|c|c|c|c|c|c|}
\hline \multirow[b]{2}{*}{ Area } & \multirow[b]{2}{*}{ River } & \multicolumn{5}{|c|}{ S04 (mg/L) } & \multirow{2}{*}{$\begin{array}{l}\text { So4/Cl } \\
\text { Median }\end{array}$} & \multirow{2}{*}{$\begin{array}{l}\text { Samples } \\
\text { (n) }\end{array}$} \\
\hline & & Min. & $10^{\text {th }}$ perc. & Med. & $90^{\text {th }}$ perc. & Max. & & \\
\hline \multirow{3}{*}{ NW } & Kemijoki & 1.4 & 1.5 & 1.8 & 2.2 & 3.0 & 2.6 & 10 \\
\hline & Simojoki & 1.1 & 1.2 & 1.4 & 1.9 & 2.7 & 1.9 & 10 \\
\hline & Kuivajoki & 1.4 & 1.6 & 1.9 & 3.0 & 4.3 & 2.1 & 10 \\
\hline \multirow{12}{*}{ W } & Oulujoki & 3.0 & 3.0 & 4.1 & 5.9 & 8.0 & 3.1 & 10 \\
\hline & Temmesjoki & 23.0 & - & 42.0 & - & 92.0 & 3.5 & 3 \\
\hline & Siikajoki & 6.4 & 7.0 & 9.4 & 13.2 & 15.0 & 4.2 & 8 \\
\hline & Pyhäjoki & 12.0 & 12.9 & 21.0 & 32.2 & 34.0 & 4.9 & 10 \\
\hline & Kalajoki & 8.1 & 8.6 & 14.0 & 18.0 & 19.0 & 3.3 & 11 \\
\hline & Lestijoki & 4.1 & 4.7 & 6.0 & 11.0 & 11.0 & 2.6 & 9 \\
\hline & Perhonjoki & 5.2 & 6.4 & 10.0 & 15.0 & 16.0 & 4.1 & 11 \\
\hline & Kruunupyynjoki & 20.0 & - & 37.5 & - & 41.0 & 8.6 & 4 \\
\hline & Ähtävänjoki & 12.0 & 13.4 & 22.5 & 33.1 & 38.0 & 4.7 & 6 \\
\hline & Lapuanjoki & 25.0 & 32.2 & 37.0 & 48.5 & 53.0 & 5.4 & 10 \\
\hline & Kyrönjoki & 30.0 & 33.0 & 39.0 & 49.0 & 53.0 & 5.3 & 32 \\
\hline & Närpiönjoki & 32.0 & - & 33.0 & - & 36.0 & 5.5 & 3 \\
\hline \multirow{3}{*}{ SW } & Sirppujoki & 89.8 & - & 94.3 & - & 98.8 & 7.9 & 2 \\
\hline & Laajoki & 26.9 & - & 27.0 & - & 32.9 & 2.5 & 3 \\
\hline & Mynäjoki & 18.0 & - & 21.0 & - & 27.0 & 2.5 & 3 \\
\hline \multirow{6}{*}{$\mathrm{s}$} & Sipoonjoki & 16.6 & - & 21.4 & - & 26.2 & 2.2 & 2 \\
\hline & Mustijoki & 10.3 & 12.0 & 13.8 & 16.4 & 21.6 & 1.8 & 11 \\
\hline & Porvoonjoki & 9.4 & 11.5 & 13.7 & 16.5 & 17.0 & 1.4 & 10 \\
\hline & Koskenkylänjoki & 8.8 & 10.2 & 11.7 & 13.5 & 23.5 & 2.1 & 11 \\
\hline & Kymijoki & 8.9 & 9.2 & 11.0 & 15.0 & 17.0 & 2.0 & 42 \\
\hline & Vehkajoki & 7.3 & - & 8.9 & - & 19.0 & 2.5 & 4 \\
\hline
\end{tabular}

NB: S: southern; SW: southwestern; W: western; NW: northwestern.

Figure 4 displays the sulfate content versus the proportion of the catchment areas below the highest shoreline of the former Litorina Sea in the surveyed catchment (\%). Figures 5 and 6 display the sulfate content and the sulfate/chloride ratio in rivers versus the extent of the high probability areas or both high and moderate probability areas in the corresponding catchments. Figure 5 shows the catchments grouped according to their sulfate contents and sulfate/ chloride ratios, while Figure 6 shows them grouped according to the mapping or modeling method utilized. Spearman rank correlation $\left(\mathrm{r}_{\mathrm{s}}\right.$ ) was used in order to reduce errors due to outliers and nonnormal distributions. The analysis was carried out within R. All correlations were significant at a 99 $\%$ level of confidence (p: 0-0.0018). The highest correlation occurs between the sulfate content and the combined high and moderate a.s. soil probability areas $\left(r_{s}=0.86\right.$; Fig. 5 and 6$)$. The correlations between the sulfate/chloride ratio and both the high probability areas and the combined high and moderate probability areas are the lowest $\left(r_{s}=0.62\right.$ and 0.60 , respectively; Fig. 5 and 6). Some of the high and moderate probability areas correspond to a.s. soils covered by peat layers (from 0.3 to more than $0.6 \mathrm{~m}$ depth) which can prevent these soils from oxidizing. The extent was thus also calculated excluding these peat-covered areas which are not leaching sulfate into the streams. Nevertheless, only a few catchments appeared to have smaller extent values when taking into account the peat-covered areas, these areas are mostly located in moderate probability zones, and they did not considerably modify the graphs. 


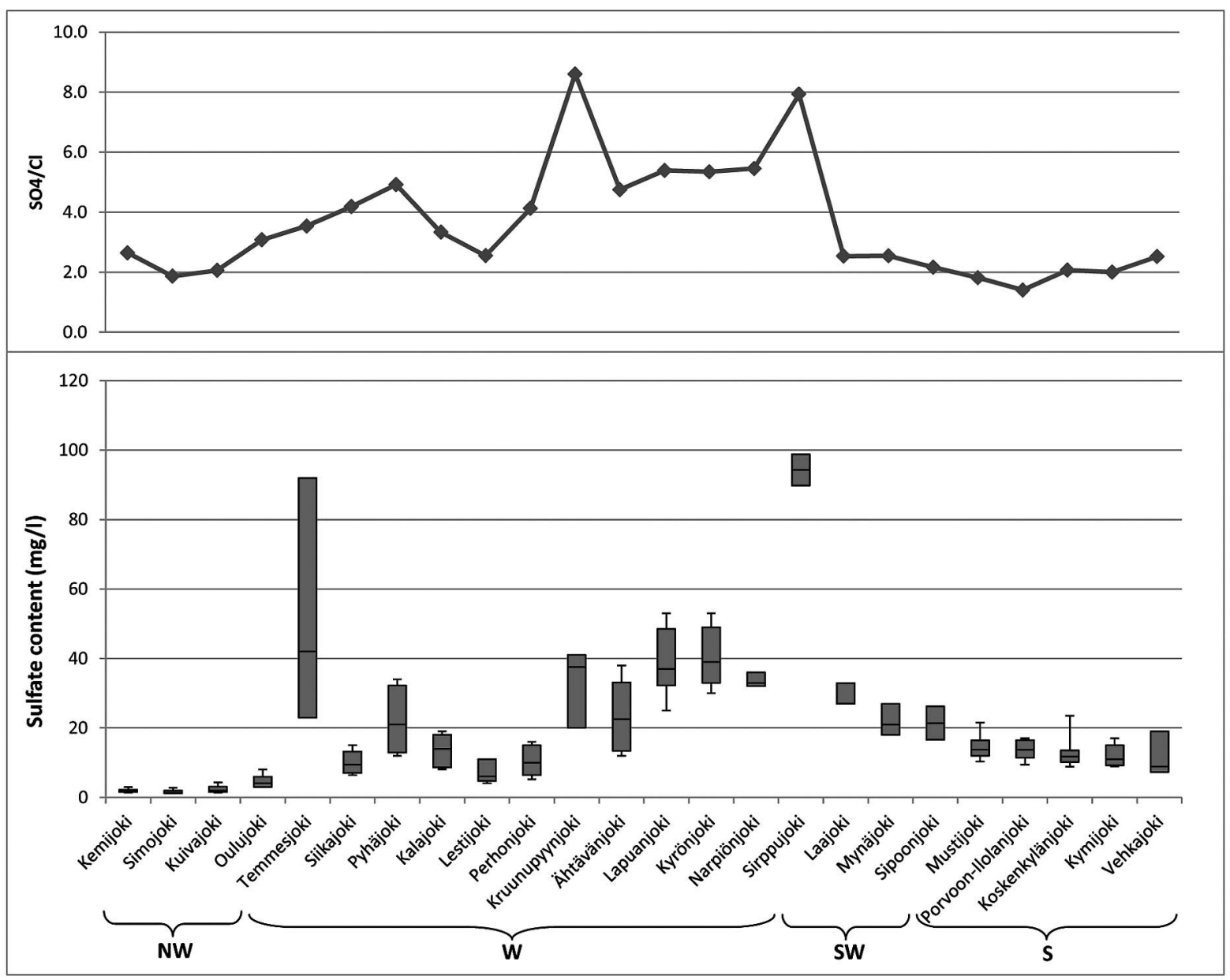

Fig. 3. Sulfate content and sulfate/chloride ratio in the rivers corresponding to the surveyed catchments along the Finnish coast (S: southern; SW: southwestern; W: western; NW: northwestern).

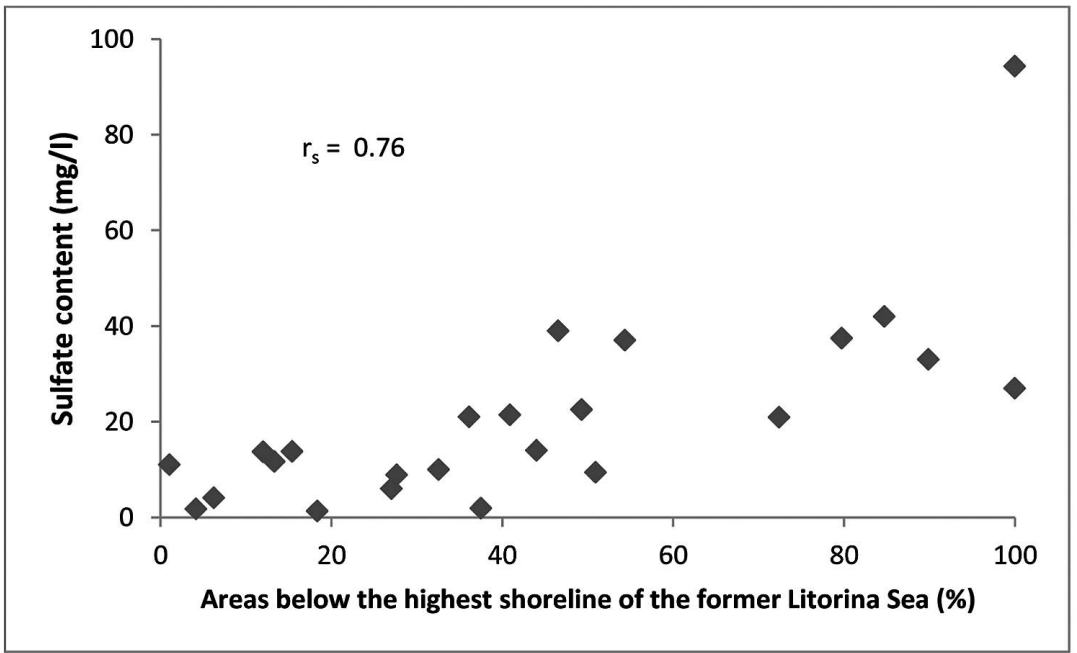

Fig. 4. Proportion of the catchment areas below the highest shoreline of the former Litorina Sea in a catchment (\%) versus median sulfate content $(\mathrm{mg} / \mathrm{l})$ in the corresponding rivers. 


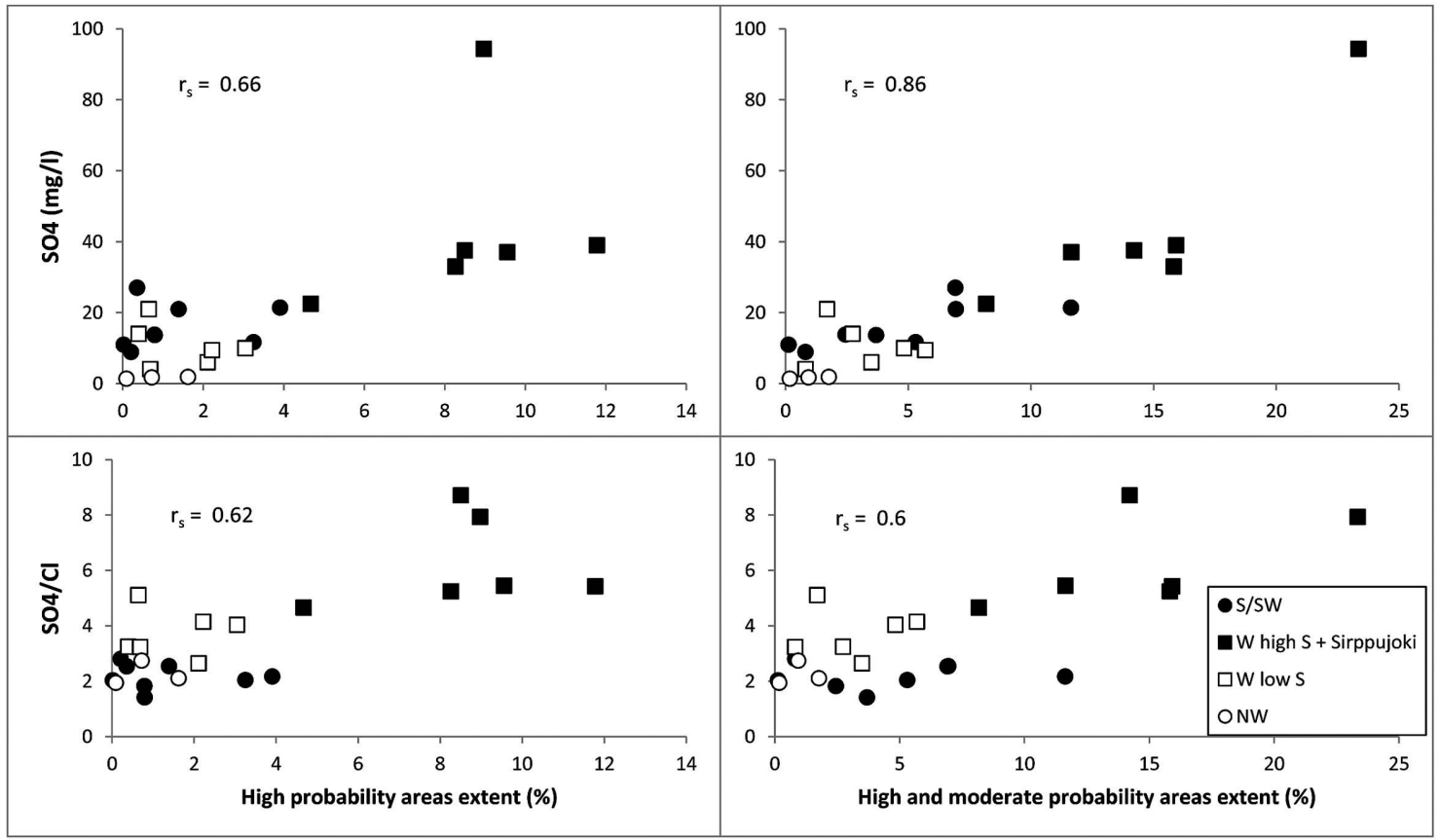

Fig. 5. Extent of a.s. soils in a catchment (\%) versus median sulfate content (mg/l) or sulfate/chloride ratio in the corresponding rivers, regionally grouped (S: southern; SW: southwestern; W: western; NW: northwestern; Temmesjoki River catchment is out of range for all graphs, data in Tables 5 and 6).

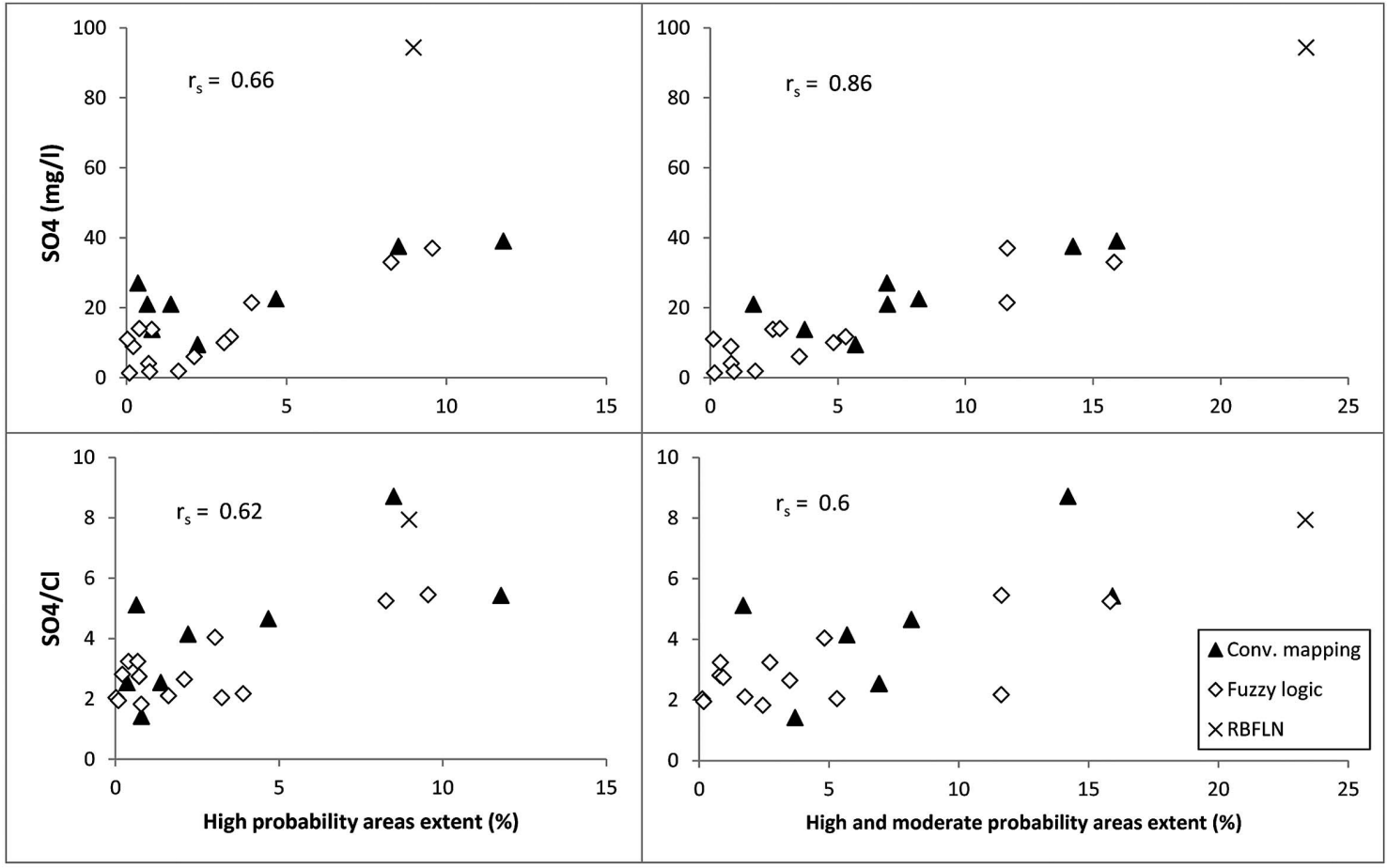

Fig. 6. Extent of a.s. soils in a catchment (\%) versus median sulfate content (mg/l) or sulfate/chloride ratio in the corresponding river, grouped according to the mapping method (S: southern; SW: southwestern; W: western; NW: northwestern; Temmesjoki River catchment is out of range for all graphs, data in Tables 5 and 6). 


\section{Discussion}

This study intends to assess a.s. soil probability maps, created with different methods, by comparing the calculated extents of a.s. soils in various catchments to water chemistry data in corresponding rivers. The impact of a.s. soils on water quality is dependent on hydrological conditions. During low flow conditions (near base flow conditions) relatively little water is discharged from a.s. soils while during extreme flow events, particularly after snow/thaw smelt, the water from a.s. soils is significantly diluted by smelt water and/or by water transported through the uppermost soil layers (Österholm and Åström, 2008). In order to compare water data from different catchments and regions, it is crucial to collate data from similar hydrological conditions when the impact of a.s. soils is relatively high. As high flow conditions occur each year in the spring in the whole country due to snow melt, it can be argued that it is easiest to find representative data from this season some weeks after the flow peak, when the flow has somewhat stabilized but is still well above base flow conditions. On the contrary, autumn hydrology is much more variable depending on the intensity of the summer drought and subsequent rain fall. Thus, it may be more difficult to find representative data for this season (Österholm and Åström, 2008). It is also necessary to account for the differences in timing of snow smelts and the subsequent high flow conditions in different regions (i.e. later snow smelt in the north than in the south). Therefore, we utilized water samples collected in April for the southern and southwestern rivers, in May for some of the western rivers (i.e. Närpiönjoki, Kyrönjoki, Lapuanjoki, Ähtävänjoki, Kruunupyynjoki and Perhonjoki Rivers), and from mid-May to mid-June for the remaining western rivers (i.e. Lestijoki, Kalajoki, Pyhäjoki, Siikajoki, Temmesjoki and Oulujoki Rivers) and the northwestern rivers.

Sulfate in recipient waters constitutes the main indicator of a.s. soils as it is directly related to sulfide oxidation. Ideally, the amount of sulfur and metals released by a.s. soils to the recipient streams is proportional to their extent in the catchment. A correlation occurs between the sulfate content of the rivers and the proportion of areas below the highest shoreline of the former Litorina Sea in the corresponding catchments $\left(r_{s}=0.76\right.$; Fig. 4), confirming that these areas constitute the potential areas for a.s. soil occurrence in Finland. For large catchments, particularly Oulujoki and Kemijoki River catchments that extend far above the former Litorina Sea limit, the sulfates (and metals) released from the lower part of the catchment are considerably diluted by the water from the upper catchment. Most of the surveyed catchments display much higher sulfate contents than typical rainwater (2-3 mg/l; Bydén et al., 2003) and also higher than the average sulfate content leached from Finnish agricultural lands (7 mg/l; Korkman, 1973). Considering the median sulfate content for brooks investigated throughout Finland ( $4 \mathrm{mg} / \mathrm{l}$; Lahermo et al., 1996), only the northwestern catchments display smaller values (i.e. Kuivajoki, Simojoki and Kemijoki River catchments; Table 6). In the southern catchments, higher sulfate contents could have been expected because of the higher salinity in the sea during their formation (salts trapped in soil pores) and in the sea spray deposited today. Moreover, this region is also closer to industrial more densely populated areas that, particularly in the past, have released sulfur dioxides in to the atmosphere.

The high sulfate contents measured in these coastal rivers together with the lack of a coherent trend with increasing sulfate contents from north to south demonstrate the importance of the presence of a.s. soils in the catchments. The most important argument for the strong impact of a.s. soils on coastal recipient waters is, however, that the extent of a.s. soils concurs well with the sulfate content in the different rivers (Table 5 and 6). The correlation between the estimated extent and corresponding recipient waters suggests that the a.s. soil probability maps created with different methods for different areas are reliable and comparable. The sulfate content correlates best with the extent of the combined high and moderate probability areas (Fig. 5 and 6), indicating that the moderate probability areas are important and should be taken into account. Most of the western catchments (i.e. Närpiönjoki, Kyrönjoki, Lapuanjoki, Ähtävänjoki, 
Kruunupyynjoki, Pyhäjoki and Temmesjoki River catchments), as well as Sirppujoki River catchment in the southwestern region, release the largest amounts of sulfate and accordingly display the largest extent values (Table 5). The southern, southwestern (excluding Sirppujoki River catchment) and northwestern catchments display low sulfate contents and accordingly small extent values (Table 5). Sirppujoki River displays extreme sulfate content and only 2 water samples were available to calculate these values (Table 6; Fig. 3), however, this concurs with the large extent values calculated for this catchment (Table 5). Temmesjoki River also displays high sulfate contents and only 3 water samples were available to calculate these values (Table 6; Fig. 3), but this still concurs with the large extent values (Table 5). Only Pyhäjoki River catchment presents unproportionally high sulfate content in comparison with its calculated a.s. soil extent, indicating that the extent may be underestimated. This may be partly explained by relatively high sulfur contents in a.s. soils in the catchment (Edén et al., 2014). Some of the western catchments (i.e. Perhonjoki, Lestijoki, Kalajoki, Siikajoki and Oulujoki River catchments) release lower than expected sulfate contents (Table 5) in the recipient waters, indicating that their extent may be overestimated.

The sulfate/chloride ratio enables distinguishing sulfate anomalies related to sulfide oxidation from those related to evapotranspiration, dilution, evaporites, sea spray or sea water intrusion. In the case of evapotranspiration (increasing concentrations of both sulfate and chloride) or dilution (decreasing concentrations), the ratio should remain fairly constant, while, in the case the sulfate originates from (relict) sea water (sulfate/chloride ratio $=0.14$ ), the ratio will decrease. Regardless of the latter processes, the sulfate/chloride ratio is, thus, expected to increase due to sulfide oxidation and the presence of a.s. soils in a catchment.

The sulfate/chloride ratios measured in many rivers demonstrate the presence of a.s. soils in the corresponding catchments, just like the sulfate contents. The sulfate/chloride ratio is coherent with the sulfate content in the rivers (i.e. the ratio is generally increasing with an increasing sulfate content; Fig. 3). This constitutes yet another indication that sulfide oxidation is the main cause of elevated sulfate concentrations. Nonetheless, in comparison to their sulfate content, Kruunupyynjoki River displays a higher than expected sulfate/ chloride ratio, while Temmesjoki River conversely presents a lower than expected ratio (Table 6 and Fig. 3). The high ratio may be explained by a very high rate of oxidation and/or sedimentation in low saline environment, or a high proportion of sulfate originating from black schists unrelated to the former (saline) Litorina Sea. The low ratio may be explained by a low rate of oxidation (i.e. a large amount of potential a.s. soils, not cultivated yet), which is confirmed as the estimated extent of a.s. soils is higher than the proportion of cultivated land in Temmesjoki River catchment (Tables 1 and 5). The extent of a.s. soils concurs fairly well with the sulfate/chloride ratio in the different rivers (fig. 5 and 6). Although some of the western catchments (i.e. Perhonjoki, Lestijoki, Kalajoki, Siikajoki and Oulujoki River catchments), had relatively low sulfate contents, a high sulfate/chloride ratio still indicates the sulfate originates from a.s. soils. The western catchments generally display higher ratios than the southern and southwestern catchments, which may be explained by a salinity about twice as high in the southern area. These southern catchments are also located closer to the sea, implying that sea spray (i.e. extremely low sulfate/ chloride ratio) might have some minor impact as well.

The correlation between the sulfate content or the sulfate/chloride ratio to the extent of a.s. soils in catchments modeled with fuzzy logic or created with conventional mapping techniques do not differ markedly (Fig. 6). Nevertheless, some of the conventionally mapped catchments seem to display relatively high sulfate values which might indicate an underestimation of the areal extent, while some catchments modeled with fuzzy logic display relatively large extent values, indicating that the extent of a.s. soils may have been overestimated with this technique. Conversely, for the modeled Simojoki, Lestijoki and Kalajoki River catchments, 
validation points corresponding to a.s. soil occurrences were relatively poorly assigned $(56,59$ and $47 \%$; Table 4), indicating an underestimation of the most probable a.s. soil areas. In contrast to conventional a.s. soils (i.e. fine-grained sediments), it was found that, in these catchments, a.s. soils often occur in relatively coarse-grained sediments and under thick peat (Boman et al., 2014). Since the models were adapted to conventional fine-grained a.s. soils, these unusual soil types were allocated low fuzzy membership values and, thus, could not appear as high probability areas. This emphasizes not only the importance of expert knowledge within fuzzy logic, but also the fact that preliminary surveys should lead to more refined models. The relatively high sulfate content in Lestijoki and Kalajoki Rivers also corroborates a probable underestimation of extent, as also indicated by the validation results (Table 6).

The potential discrepancies for some catchments and between methods (Fig. 5 and 6) leading to over- or underestimation of the extent may be explained by variations in the sulfur content in different a.s. soils (i.e. inherent sulfur content or rate of depletion), variations in the activity/drainage of the a.s. soils, as well as the occurrence of black schist in the catchment. It is notable that some areas mapped in this study not only include actual a.s. soils, but also potential a.s. soils, and thus could release much larger amounts of sulfate. On the other hand, potential a.s. soils are expected to be relatively scarce, especially in the western and southern parts of Finland, most of the a.s. soils being already drained as they are considered as the most valuable farmlands. This could also explain the case when a catchment displays a large extent value but a relatively low sulfate or sulfate/chloride ratio. Even with a less than perfect estimation of the a.s. soil extent in a catchment, we can still carry out a first assessment of the mapping project.

Considering these two chemical indicators and the calculated extents of a.s. soils, the surveyed catchments can be grouped as follows: (1) the western catchments (i.e. Närpiönjoki, Kyrönjoki, Lapuanjoki, Ähtävänjoki, Kruunupyynjoki and Temmesjoki River catchments), as well as the
Sirppujoki River catchment in the southwestern region, with high sulfate contents, high sulfate/ chloride ratios and large a.s. soil extents, (2) the remaining western catchments with low sulfate contents, high sulfate/chloride ratios and small a.s. soil extents, (3) the southern and southwestern catchments (excluding Sirppujoki River catchment) displaying low and intermediate sulfate contents, respectively, low sulfate/chloride ratios and small a.s. soil extents, and (4) the northwestern catchments displaying very low sulfate contents, low sulfate/ chloride ratios and very small extents (Fig. 3).

Puustinen et al. (1994) estimated the extent of Finnish cultivated a.s. soils (c. $3,000 \mathrm{~km}^{2}$ ) by using limited data (soil profiles investigated down to 200 cm depth only) and, by today's standards, inappropriate criteria for classification (subsoil $\mathrm{pH}$ $<5.0$ and no sulfur content criterion). Later, YliHalla et al. (1999) carried out another estimation using more strict criteria (a.s. soil had to be met within $125 \mathrm{~cm}$ or $150 \mathrm{~cm}$ of the soil surface), but on the same insufficient data, leading to a much smaller extent $\left(600-1,300 \mathrm{~km}^{2}\right)$. For this study, a novel classification system and sampling scheme, more suited for Boreal a.s. soils (Edén et al., 2012), were applied. Samples were taken down to $300 \mathrm{~cm}$, not only from cultivated areas, but also from forest and peat-covered areas. They were also incubated, enabling us to identify and take into account potential a.s. soils (Beucher et al., 2013). An estimate of the a.s. soil extent for the southern part of the Finnish coastal areas (i.e. from Närpiönjoki River catchment to the Russian border) has previously been assessed using the very high probability class (i.e. with fuzzy membership from 0.75 to 1 ) from the most accurate fuzzy logic model (Beucher et al., 2014). The calculated extent was in the order of $800 \mathrm{~km}^{2}$ (c. $5 \%$ of a total surface of $17,300 \mathrm{~km}^{2}$, below the highest shoreline of the former Litorina Sea). In the present study, the extent of the most probable areas for a.s. soil occurrence (i.e. high probability areas for both maps and models) for the 24 surveyed catchments is in the order of 2,600 $\mathrm{km}^{2}$ (c. $12 \%$ of a total surface of $21,300 \mathrm{~km}^{2}$, below the highest shoreline of the former Litorina Sea). This value constitutes a rather conservative estimate 
as it only accounts for the high probability areas. As expected, this extent is much larger than the value calculated for the southern part of the Finnish coastal areas (Beucher et al., 2014). Since the surveyed areas in this study covered only about 43 $\%$ of the whole coastal areas, excluding many catchments where a.s. soils can be expected, the extent of a.s. soils for the whole coastal areas (covering c. 50,100 $\mathrm{km}^{2}$, below the highest shoreline of the former Litorina Sea) would obviously be much larger than the previous estimates. More accurate estimates will be provided through the ongoing mapping work coordinated by GTK.

All things considered, utilizing a.s. soil related chemical indicators in water as suggested here constitutes a complementary, independent and straightforward tool to assess probability maps in regard to the extent of a.s. soils. This assessment also helps in getting an overview of the mapping results, determining regional features, as well as the limits of our maps. Collating soil and water data enables estimating the presence of a.s. soils in different catchments, clearly indicating outlying catchments which would require some corrections or additional soil sampling. The progress of a.s. soils mapping in Finland can, thus, be properly assessed using all available data. In the future, water chemistry data could also be utilized for assessment of a.s. soil mapping at "sub-catchment" scale. This would require sampling water along the main river, as well as in secondary streams in a catchment. Water samples could corroborate the localization and extent of a.s. soils probability areas in sub-areas of a catchment.

\section{Conclusion}

Acid sulfate (a.s.) soil mapping constitutes a critical step for effective mitigation of hot spot areas affecting large water bodies. Assessing the mapping results also represents a crucial stage, whether using conventional mapping or a spatial modeling method. Comparing the mapped or modeled extent of a.s. soils in different catchments to a.s. soil related chemical indicators in the recipient waters offers an independent and straightforward tool to evaluate the reliability and comparability of the a.s. soil maps. The high sulfate contents and sulfate/chloride ratios measured in many rivers demonstrate the presence of a.s. soils in the corresponding catchments. The extent of the most probable areas for a.s. soils, calculated for the different surveyed catchments, correlates with the water chemistry data, suggesting that the a.s. soil probability maps created with different methods for different areas are reliable and comparable. In particular, the best correlation found between the sulfate content and the extent of the combined high and moderate probability areas demonstrates that the moderate probability areas are important and should be taken into account as well as the high probability areas. Notably, the correlation between the sulfate content or the sulfate/chloride ratio to the extent of a.s. soils in catchments modeled with fuzzy logic or created by conventional mapping techniques do not differ markedly. Spatial modeling techniques, thus, yield results which concur with conventional mapping's results, using much less points, confirming that spatial modeling techniques can efficiently complement conventional mapping (Beucher et al., 2014). Collating soil and water data enables estimating the presence of a.s. soils in different catchments, markedly indicating outlying catchments which would require some corrections or additional soil sampling. This assessment also helps in getting an overview of the mapping results, determining regional features, as well as the limits of our maps. Finally, a total extent could be estimated for the combined 24 surveyed catchments, a rather conservative estimate only accounting for the high probability areas (c. $2,600 \mathrm{~km}^{2}$, i.e. $12 \%$ of a total surface of $21,300 \mathrm{~km}^{2}$ ). The extent for the whole coastal areas (c. 50,100 $\mathrm{km}^{2}$ ) can, thus, be expected to be much larger than the previous estimates.

\section{Acknowledgements}

The authors thankfully acknowledge the financial support from the VALUE Graduate School, Maaja Vesitekniikan Tuki ry, Stiftelsens för Åbo Akademi Forskningsinstitut and K. H. Renlunds stiftelsen. 
We would also like to thank Dr. Vanessa Wong, Dr. Zenah W. Orndorff and Dr. Antti E. Ojala for their valuable comments which enabled considerable improvements to the manuscript.

\section{References}

Airo, M-L. \& Loukola-Ruskeeniemi, K. 2004. Characterization of sulfide deposits by airborne magnetic and gamma-ray responses in eastern Finland. Ore Geology Reviews 24, pp. 67-84. http://dx.doi.org/10.1016/j.oregeorev.2003. 08.008

Åström, M., Sundström, R., Holmberg, M. \& Storberg, K.-L. 2005. $\mathrm{pH}$ of streams in western Finland - a perspective from the middle ages into the mid- $21^{\text {st }}$ century. Agricultural and Food Sciences 14, pp. 5-13. http:// dx.doi.org/10.2137/1459606054224183

Beucher, A., Österholm, P., Martinkauppi, A., Edén, P. \& Fröjdö, S. 2013. Artificial neural network for acid sulfate soil mapping: Application to the Sirppujoki River catchment area, south-western Finland. Journal of Geochemical Exploration 125, pp. 46-55. http:// dx.doi.org/10.1016/j.gexplo.2012.11.002

Beucher, A., Fröjdö, S., Österholm, P., Martinkauppi, A. \& Edén, P. 2014. Fuzzy logic for acid sulfate soil mapping: application to the southern part of the Finnish coastal areas. Geoderma 226-227, pp. 21-30. http://dx.doi.org/ 10.1016/j.geoderma.2014.03.004

Boman, A., Edén, P., Österholm, P., Auri, J. \& Mattbäck, S., 2014. Coarse-grained low-sulfur acid sulfate soil materials in Finland. In: (eds) 20 $0^{\text {th }}$ World Congress of Soil Science, Jeju, South Korea 2014. Proceedings volume in press.

Bonham-Carter, G.F. 1994. Geographic Information Systems for Geoscientists - Modeling with GIS. Computer Methods in the Geosciences 13. Pergamon, Oxford. $398 \mathrm{p}$.

Bydén, S., Larsson, A.-M., Olsson, M. 2003. Mäta vatten Undersökningar av sött och salt vatten. Institutionen för miljövetenskap och kulturvård, Göteborgs universitet.

Donner, J. 1995. The Quaternary History of Scandinavia: World and Regional Geology 7. Cambridge, United Kingdom, Cambridge University Press. 199 p.

Edén, P., Rankonen, E., Auri, J., Yli-Halla, M., Österholm, P., Beucher, A. \& Rosendahl, R. 2012. Definition and classification of Finnish Acid Sulfate Soils. In: Österholm, P., Yli-Halla, M. \& Edén, P. (eds) $7^{\text {th }}$ International Acid Sulfate Soil Conference, Vaasa, Finland 2012. Proceedings volume. Geological Survey of Finland, Guide 56, pp. 2930 .

Edén, P., Auri, J., Boman, A. ja Rankonen, E., 2014. Happamien sulfaattimaiden kartoitus (1:250 000) ja ominaisuudet. In: Suomela, R. (toim.), Edén, P., Huhmarniemi, A.,
Saarinen, T., Tertsunen, J., Auri, J., Marttila, H., Yli-Halla, M., Boman, A., Joki-Tokola, E., Luoma, S. ja Rankonen, E. Happamat sulfaattimaat ja niistä aiheutuvan vesistökuormituksen hillitseminen Siika- ja Pyhäjoen valuma-alueilla. MTT Raportti 132, MTT Jokioinen, pp. $12-36$.

HERTTA database, 2014. OIVA-environment and geographic information service, Finnish Environment Institute. http:/ /wwwp2.ymparisto.fi/tietoapalvelusta.html. Last accessed: May 162014.

Hildén, M. \& Rapport, D. 1993. Four centuries of cumulative impacts on a Finnish river and its estuary: an ecosystem health-approach. Journal of Aquatic Ecosystem Health 2, pp. 261-275. http://dx.doi.org/10.1007/bf00044030

Hudd, R. \& Leskelä, A. 1998. Acidification-induced species shifts in coastal fisheries off the river Kyrönjoki, Finland: a case study. Ambio 27, pp. 535-538.

Lahermo, P., Väänänen, P., Tarvainen, T., Salminen, R. 1996. Geochemical Atlas of Finland, part 3: Environmental geochemistry - stream waters and sediments. Geological Survey of Finland, Espoo, Finland. 149 p.

Korkman, J. 1973. Sulphur status in Finnish cultivated soils. J. Scient. Agric. Soc. Finl. 45, pp. 121-215.

Looney, C.G. 2002. Radial basis functional link nets and fuzzy reasoning. Neurocomputing 48, pp. 489-509. http:// dx.doi.org/10.1016/s0925-2312(01)00613-0

McBratney, A.B., Odeh, I.O.A. 1997. Application of fuzzy sets in soil science: fuzzy logic, fuzzy measurements and fuzzy decisions. Geoderma 77, pp. 85-113. http://dx.doi.org/ 10.1016/s0016-7061(97)00017-7

Nyberg, M. E., Österholm, P. \& Nystrand, M. 2011. Impact of acid sulfate soils on the geochemistry of rivers in southwestern Finland. Environmental Earth Sciences 66, pp. 157-168. http://dx.doi.org/10.1007/s12665-011$1216-4$

Ojala, A.E.K., Palmu, J.-P., Åberg, A., Åberg, S. \& Virkki, H. 2013. Development of an ancient shoreline database to reconstruct the Litorina Sea maximum extension and the highest shoreline of the Baltic Sea basin in Finland. Bulletin of the Finnish Geological Society 85, 127-144.

Österholm, P., Åström, M. 2002. Spatial trends and losses of major and trace elements in agricultural acid sulphate soils distributed in the artificially drained Rintala area, W. Finland. Applied Geochemistry 17, pp. 1209-1218. http:// dx.doi.org/10.1016/s0883-2927(01)00133-0

Österholm, P., Åström, M. 2008. Meteorological impacts on the water quality in the Pajuluoma acid sulphate area, W. Finland. Appl. Geochem. 23, pp. 1594-1606. http:// dx.doi.org/10.1016/j.apgeochem.2008.01.011

Österholm, P., Edén P., Martinkauppi, A., Beucher, A., YliHalla, M. \& Auri, J. 2010. Mapping and characterization of Boreal acid sulfate soils. In: Gilkes, R. And Prakongkep, N. (eds) $19^{\text {th }}$ World Congress of Soil Science, Soil Solutions for a Changing World, Brisbane, Australia 2010. 
Proceedings volume 3. Australian Society of Soil Science, pp. 2171-2174.

Puustinen, M., Merilä, E., Palko, J. \& Seuna, P. 1994. Kuivatustila, viljelykäytäntö ja vesistökuormitukseen vaikuttavat ominaisuudet Suomen pelloilla. Summary: Drainage level, cultivation practices and factors affecting load on waterways in Finnish farmland. National Board of Waters and Environment, Research report A198.

Saarinen, T., Vuori, K.-M., Alaraarela, E. \& Kløve, B. 2010. Past and future seasonal variations in $\mathrm{pH}$ and metal concentrations in runoff from river basins on acid sulphate soils in Western Finland. Journal of Environmental Science and Health, Part A: Toxic/Hazardous Substances and Environmental Engineering 47 (11), pp. 1614-1625. http://dx.doi.org/10.1080/10934529.2012.680783

Sawatzky, D.L., Raines, G.L., Bonham-Carter, G.F., \& Looney, C.G. 2009. Spatial Data Modeller (SDM): ArcMAP 9.3 geoprocessing tools for spatial data modelling using weights of evidence, logistic regression, fuzzy logic and neural networks, http://arcscripts.esri.com/details.asp?dbid $=15341$.

Soil Survey Staff, 1999. Soil Taxonomy. A basic system of soil classification for making and interpreting soil surveys. Agriculture Handbook 436, 2nd Ed.

Suppala, I., Lintinen, P. \& Vanhala, H. 2005. Geophysical characterising of sulphide rich fine-grained sediments in Seinäjoki area, western Finland. Geological Survey of Finland, Special Paper 38, pp. 61-71.

Taipale, K., \& Saarnisto, M. 1990. Tulivuorista jääkausiin: Suomen maankamaran kehitys. Porvoo: WSOY. 416 p.

Toivonen, J., Österholm, P. \& Fröjdö, S. 2013. Hydrological processes behind annual and decadal-scale variations in the water quality of runoff in Finnish catchments with acid sulfate soils. Journal of Hydrology 487, pp. 60-69. http://dx.doi.org/10.1016/j.jhydrol.2013.02.034

Triipponen, J.-P. 1997. Sirppujoen valuma-alueen happamuustutkimus. Lounais Suomen ympäristökeskus, 43 p.

Vanhala, H., Suppala, I., Lintinen, P. 2004. Integrated geophysical study of acid sulphate soil area near Seinäjoki, Southern Finland. In: Sharing the Earch: EAGE 66th Conference \& Exhibition, Paris, France, 7-10 June 2004: extended abstracts. Houten: EAGE. 4 p. Optical disc (CDROM).

Water Framework Directive (Directive 2000/60/EC of the European Parliament and of the Council establishing a framework for Community action in the field of water policy. Council of European Communities. Official Journal L 327 of 23rd October 2000.

Wohlfarth, B., Björck, S., Funder, S., Houmark-Nielsen, M., Ingólfsson, Ó., Lunkka, J-P., Mangerud, J., Saarnisto, M. \& Vorren, T., 2008. Quaternary of Norden. Episodes 31, pp. 73-81.

Yli-Halla, M., Puustinen, M. \& Koskiaho, J. 1999. Area of cultivated acid sulfate soils in Finland. Soil Use and Manage. 15, pp. 62-67. http://dx.doi.org/10.1111/ j.1475-2743.1999.tb00065.x

Zadeh, L. A. 1965. Fuzzy sets. Institute of Electric and Electronic Engineering, Information and Control 8, pp. 338-353. http://dx.doi.org/10.1016/s0019-9958(65) 90241-x

Zell, A., Mamier, G., Vogt, M., Mache, N., Hübner, R., Döring, S., Hermann, K.-U., Soyez, T., Schmalzl, M., Sommer, T., Hatzigeorgiou, A., Posselt, D., Schreiner, T., Kett, B., Clemente, G., Wieland, J. 1998. SNNS Stuttgart Neural Network Simulator User Manual, Version 4.2. IPVR, University of Stuttgart and WSI, University of Tübingen. http://www.ra.cs.uni-tuebingen.de/SNNS/. 